\title{
Evaluating the moderating impact of family on the relationship between board independence and corporate social responsibility using propensity score matching
}

\begin{tabular}{|c|c|}
\hline $\begin{array}{l}\text { Authors: } \\
\text { Rehana Anwa } \\
\text { Jaleel Ahmed }\end{array}$ & \\
\hline $\begin{array}{l}\text { Affiliations: } \\
{ }^{1} \text { Department } \\
\text { Sciences, Fact } \\
\text { Management } \\
\text { Sciences, Cap } \\
\text { of Science anc } \\
\text { Islamabad, Pa }\end{array}$ & $\begin{array}{l}\text { Ity of } \\
\text { and Social } \\
\text { tal University } \\
\text { Technology, } \\
\text { kistan }\end{array}$ \\
\hline $\begin{array}{l}\text { Correspondin } \\
\text { Rehana Anwa } \\
\text { pm121008@c }\end{array}$ & $\begin{array}{l}\text { g author: } \\
\text { ust.pk }\end{array}$ \\
\hline $\begin{array}{l}\text { Dates: } \\
\text { Received: } 20 \\
\text { Accepted: } 11 \\
\text { Published: } 28\end{array}$ & $\begin{array}{l}\text { Jov. } 2019 \\
\text { Mar. } 2020 \\
\text { May } 2020\end{array}$ \\
\hline $\begin{array}{l}\text { How to cite th } \\
\text { Anwar, R., \& A } \\
\text { Evaluating the } \\
\text { impact of fam } \\
\text { relationship b } \\
\text { independence } \\
\text { social respons } \\
\text { propensity scc } \\
\text { South African } \\
\text { Business Man } \\
\text { a1854. https:/ } \\
\text { 10.4102/sajbr }\end{array}$ & $\begin{array}{l}\text { is article: } \\
\text { hmed, J. (2020). } \\
\text { moderating } \\
\text { ily on the } \\
\text { etween board } \\
\text { and corporate } \\
\text { ibility using } \\
\text { re matching. } \\
\text { Journal of } \\
\text { agement, 51(1), } \\
\text { /doi.org/ } \\
\text { n.v51i1.1854 }\end{array}$ \\
\hline $\begin{array}{l}\text { Copyright: } \\
\text { (c) 2020. The } \\
\text { Licensee: AOS } \\
\text { is licensed un } \\
\text { Creative Com } \\
\text { Attribution Lic }\end{array}$ & $\begin{array}{l}\text { luthors. } \\
\text { IS. This work } \\
\text { der the } \\
\text { nons } \\
\text { ense. }\end{array}$ \\
\hline Read online: & \\
\hline 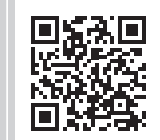 & $\begin{array}{l}\text { Scan this QR } \\
\text { code with your } \\
\text { smart phone or } \\
\text { mobile device } \\
\text { to read online. }\end{array}$ \\
\hline
\end{tabular}

Purpose: Owing to the voluntary nature of CSR activities, the decision to participate or not could be affected by the motives of corporate directors. The purpose of this research was to investigate whether family involvement in business moderates the relationship between board independence and sustainability performance of firms.

Design/methodology/approach: Firstly, propensity score matching is employed to control for the problem of potential endogeneity in the sample by generating a matched sample. Later, regression analysis is conducted on this matched sample to check for the moderating impact of family-led firms on the relation between board independence and CSR performance (CSRP) of firms.

Findings/results: We document about Chinese firms with independent boards exhibiting socially responsible behaviour which shows that they serve in a monitoring capacity over the management on behalf of rest of the stakeholders. Moreover, our results show that the role of independent directors is compromised in establishing effective monitoring in family-led firms.

Practical implications: Our results would help regulating agencies in designing regulatory programs by guiding them in developing customized policies for different governance and ownership systems in place. Our findings recommend that in a bid to attain improved sustainability performance, diversified shareholding may be favoured or requisite codes may be framed to enhance the social performance of firms having concentrated ownership.

Originality/value: This work essentially clears the varying results in literature with regard to the relationship of board characteristics and firms' CSRP.

Keywords: corporate social responsibility (CSR) performance; board independence; family firms; propensity score matching; Chinese firms.

\section{Introduction}

Today, family businesses dominate the economic landscape of the world (Meglio, 2019). This ubiquity of family firms has attracted the interests of various scholars in studying behaviours and characteristics of these firms. The main research question has been to investigate if family-owned firms make different strategic choices than their non-family counterparts. Prior literature has looked into factors such as governance mechanisms, leadership, performance and succession, but it overlooked areas like sustainability performance (De Massis, Chirico, Kotlar, \& Naldi, 2013). In the light of growing global awareness, there is an increasing pressure on firms to go beyond the goal of generating value for investors only (Saeidi, Sofian, Saeidi, Saeidi, \& Saaeidi, 2015). In response to this pressure, companies participate in corporate social responsibility (CSR) activities to appear socially responsible, thereby strengthening relations with their stakeholders (Tate \& Bals, 2018). However, owing to the voluntary nature of sustainability activities, the decision to participate or not in CSR activities could be affected by the motives and preferences of directors on corporate boards (Frias-Aceituno, Rodriguez-Ariza, \& Garcia-Sanchez, 2013). Generally, board independence guarantees enhanced transparency, as this attribute indicates improved level of compliance with regulations and responsible behaviour (Goh, Lee, Ng, \& Ow Yong, 2016). Moreover, independent boards take into consideration the welfare of all stakeholders. As a result, it is anticipated that independent boards promote involvement in social and environmental activities, as these activities benefit all stakeholders. 
Furthermore, after the global financial crisis of 2008, the corporate governance (CG) rules were revised in many countries, and an urgent need for strong outsider-dominated board was emphasised. Consequently, the number of independent directors has increased considerably on corporate boards. Thus, it is expected that sustainability performance, which is usually encouraged by independent boards, would increase in family-led firms subject to the presence of independent directors.

Nevertheless, some researchers have argued that nominations in the boards of family-led firms are generally put forth from within the family circle or based on personal relationships, specifically in the case of independent directors (Chrisman, Memili, \& Misra, 2014). Therefore, the presence of family members can have a significant influence on a board's behaviour (Collin \& Ahlberg, 2012). In consequence, it is expected that independent board members may just give their seal of approval to the decisions already taken by family members (Bardhan, Lin, \& Wu, 2014). Hooy, Hooy and Chee (2019) pointed to the pattern of missing control mechanisms in businesses led by families, possibly because of the involvement of family members in the day-to-day affairs of firms. In addition, family businesses have a tendency to take sustainability practices as a toll instead of as an opportunity; therefore, they are more concerned about the financial outcomes, compared to the social responsibility of their firms (Morck \& Yeung, 2003). Based on the above line of reasoning, we hypothesise a moderating impact created by the negative behaviour of family members with regard to a positive relationship between board independence and CSR performance (CSRP).

China is an emerging economy, having a significantly different impact of governance structure on sustainability activities, compared to developed economies, where most of the research on this topic has been conducted. Moreover, the empirical evidence on board independence and CSRP remains inconclusive even after controlling for endogeneity bias (Guerrero-Villegas, Pérez-Calero, Hurtado-González, \& Giráldez-Puig, 2018). Therefore, to tackle the problem of endogeneity, we employed propensity score matching (PSM) in our study. Hence, this article targets to fill this void in CSR literature that holds significant implications to various stakeholders, specifically the regulators in China. The findings of this article show that there exists a positive relationship between the presence of independent directors on the board and CSR engagement in non-family firms, but no such relationship is found in family firms. Such a finding reflects that effectiveness of an independent board for attaining enhanced sustainability performance depends on the ownership arrangement of a firm. Our findings corroborate with the idea of Corbetta and Salvato (2004) that the roles and characteristics of corporate boards differ for various kinds of firms, implying the need of customised governance structures according to the multifaceted needs of companies. Furthermore, our results extend valuable guidance to regulators and investors of emerging economies on the efficacy of mandating the independent directors' inclusion to the boards, specifically in firms where the family is a dominant owner. Such findings clearly hint at the usefulness of having a different set of guidelines for family firms from that of non-family firms. The current rules and requirements of CG practices, including the appointment of independent directors, are grounded in the notion of 'one size fits all'. On the contrary, our results classify this approach as less effective in improving the sustainability performance of all firms.

\section{Prior research and hypotheses development Corporate board independence and corporate
social responsibility performance}

Contemporary research has emphasised the importance of the monitoring role played by independent boards in the settlement of agency conflicts, which usually arise because of the long-term nature of CSR investments. Generally, CSR activities demand considerable long-term investments without instant financial rewards. Hence, self-serving managements might abstain from taking CSR-related projects because of its short tenures (Liao, Lin, \& Zhang, 2018). However, CSR investments are anticipated to provide longterm benefits to stockholders by virtue of easy access to finance, improved reputation and reduced risk (Saeidi et al., 2015). This long-term nature of CSR investments leads to divergence of interest between the principal and the agents (Albuquerque, Koskinen, \& Zhang, 2018; Tauringana \& Chithambo, 2015). As self-serving activities of managements cannot be countered by legislative action, the monitoring role of corporate boards becomes increasingly important in such situations (Roe, 1991).

Research demonstrates that besides economic resources, a fundamental element required by companies to initiate sustainability-related activities is relational and human capital (Tate \& Bals, 2018). Projects related to CSR require peopleintensive structures and cross-functional coordination for successful designing and execution (Pohl \& Tolhurst, 2010). Generally, independent directors contribute to a firm's relational and human capital by providing professional expertise, competencies, external links and unique skills (Chen, Hsu, \& Chang, 2016). This valuable human capital helps firms in resolving environmental uncertainties, acquiring vital resources and managing external dependencies, resulting in enhanced sustainability performance (Ramón-Llorens, García-Meca, \& Pucheta-Martínez, 2018). In the same vein, Liao, Luo and Tang (2015) maintained that independent directors create environmental opportunities by utilising their specific expertise. Furthermore, literature also cites that diverse backgrounds and good stakeholder orientation edify independent directors' capabilities in maintaining a trade-off between environmental and financial accountability (Al-Dah, 2019). This strengthens corporate boards towards attaining a fine balance between short- and long-term goals, leading to varying interests of multiple stakeholders being accommodated. 
In addition, the independent directors remain cautious for stakeholders' demands; hence, they develop CSR campaigns based on innovative vision, which ultimately enhances firm's competitiveness and prestige in the society (Garcia-Sanchez, 2014) and also proves to be helpful for the continuation of their directorship (De Villiers, Naiker, \& Van Staden, 2011). Independent directors have a good stakeholder orientation because of their diverse backgrounds and are generally more capable of managing external contingencies (Liao et al., 2015). Moreover, the lack of financial stake of these directors makes them more capable of balancing between financial and social accountability (Wang \& Dewhirst, 1992). This shows that they would focus on a broader view of firm performance as opposed to the narrow view, which is all about financial gains. The above-mentioned arguments lead to the first hypothesis of the study:

H1: There exists a positive relation between board independence and CSR performance of a firm.

\section{Moderation of family firms}

Our next research objective was to examine if family control moderates the relation of board independence and CSR. The two contrasting theoretical opinions regarding the association between family businesses and corporate social performance are found in the literature.

One line of research suggests that family firms are less socially responsible. In this context, Kellermanns, Eddleston and Zellweger (2012) pointed out that family firms are more concerned with financial returns, owing to their huge financial investments in the firms. Singal (2014) showed that family firms with ample resources considered sustainability activities merely as an expense and not as a management strategy or an opportunity to improve firm performance. In addition, family firms are found to behave responsibly as well as irresponsibly at the same time. They show responsible behaviour for external stakeholders in a bid to save reputation and compromise when dealing with internal stakeholders for ensuring control (Cruz, Larraza-Kintana, Garcés-Galdeano, \& Berrone, 2014).

Another line of research with a socio-emotional wealth (SEW) perspective argues that family businesses generally focus on non-economic goals, for instance, longevity, preservation of reputation in public and identity (Blodgett, Dumas, \& Zanzi, 2011). Family firms are guided by the desire of passing down a viable heritage; hence, family businesses indulge in sustainability activities so that future generations can inherit a firm with a positive image (Miller \& Le Breton-Miller, 2006).

The diverse results based on the views of agency and SEW perspectives can be understood in the light of contingency theory, which suggests that the relationship between two variables can vary with context or culture (Mokhtar, Jusoh, \& Zulkifli, 2016). In this background, Bing and Li (2019) showed that indulging in CSR activities may adversely affect the financial performance (FP) of firms, which explains that family businesses would opt for CSR engagement only in case it adds to firms' reputation and welfare (Zellweger, Nason, Nordqvist, \& Brush, 2013). In this context, literature has found that family involvement in firms is negatively linked with sustainability practices (Labelle, Hafsi, Francoeur, \& Ben Amar, 2018; Nekhili, Nagati, Chtioui, \& Rebolledo, 2017). Moreover, the long-term nature of CSR pay-off might clash with the risk-averse nature of family ownership (Chrisman \& Patel, 2012), which explains why family firms avoid investing in CSR activities.

These discussions consequently point towards a strong conflict of interests between independent directors and family directors. Generally, family firms are majorly owned and managed by family members (Chu, 2011). This distinguishing feature of family firms may affect the behaviour of board members, including independent directors. Furthermore, a great degree of nepotism is observed when it comes to the selection of directors in family firms and especially in the appointment of outside directors (Gabrielsson \& Huse, 2005). In brief, family businesses generally resort to informal control mechanisms, for example, hiring and promotion of candidates who carry the same values as that of the family members (Collin \& Ahlberg, 2012). Consequently, principal-agent conflict is resolved but at the same time principal-principal conflict is raised, which increases the influencing ability of family members in calling the shots and ultimately weakening the true spirit of the CG system. Accordant with this logic are the findings of GarcíaRamos \& García-Olalla (2011), which further support the idea that an independent director's role in family-led firms is ceremonial and is limited to just providing resources and not performing a monitoring task. Therefore, board meetings in family firms are conducted just to give a formal approval to what the family directors have already decided (Gabrielsson \& Huse, 2005). Against this background, Leung, Richardson and Jaggi (2014) provided evidence that the positive relation between board independence and firm performance is weaker in family-led firms. This indicates that the effectiveness of independent board is jeopardised under family leadership. Along the same lines, Cho and Kim (2007) showed a weak positive impact of independent directors on firm performance, which is mitigated by the concentrated ownership structure in a negative fashion. Although GomezMejia, Cruz and Imperatore (2014) reported a positive impact of founding family corporations on financial disclosure, Darmadi (2013) showed that family presence curtails the effectiveness of an independent board.

Recent studies (García-Sánchez, Gómez-Miranda, David, \& Rodríguez-Ariza, 2019; Jizi, 2017; Muttakin, Khan, \& Mihret, 2018) have investigated the relationship between board independence without including or controlling for the ownership pattern in their research models. This consequently leads to biased results because CG literature shows that ownership is one of the major determinants of CSRP $(\mathrm{Hu}$, Zhu, Tucker, \& Hu, 2018). Some studies that considered ownership structures either did not control for endogeneity 
effectively (Bansal, Lopez-Perez, \& Rodriguez-Ariza, 2018; Chang, Oh, Park, \& Jang, 2017) or employed a sample from developed countries (Cuadrado-Ballesteros, RodríguezAriza, \& García-Sánchez, 2015). Du, Weng, Zeng, Chang and Pei (2017) proposed that CSR is country-specific and recommended to specially study the emerging markets for this reason. Our study contributes to the CSR literature with evidence from one of the largest developing markets in South Asia, namely, China.

In line with the above arguments, we hypothesise that independent directors discourage participation in CSR activities owing to family members' desire. Based on the above discussion and empirical evidence, the following hypothesis is proposed about the moderating role played by family control:

H2: The positive relation between board independence and CSR performance is moderated by family firms.

\section{Research design Institutional background for the Chinese context}

China is an ideal setting for this study because family-led business structures are comparatively more prominent in emerging economies (Yu, Lumpkin, Sorenson, \& Brigham, 2011). In China, corporate ownership is centralised in the hands of a few families (Yuan, Hua, \& Junxi, 2008). Moreover, through the mechanism of pyramidal ownership, controlling families usually enjoy extra power and consequently have more potential as well as incentive to expropriate the stakes of minority shareholders (García-Ramos \& García-Olalla, 2011). These family-led businesses routinely appoint friends and family on governance boards and in management positions to maintain control and protect their personal interests. Given the structure of ownership, the nature of agency problem in China is very different from the Western world, which is intensified by the weak market control mechanism. Such a situation turns into a special case for independent directors, where they are expected to safeguard the rights of minority shareholders of family-led firms.

\section{Sample selection}

The sample consists of all private non-financial A-share listed firms on Shenzhen and Shanghai stock markets. We obtained data from China Stock Market and Accounting Research (CSMAR) database. After dropping observations with omitted variables, a final sample of 3960 observations over the period of 2008-2017 was used for analysis.

\section{Variables}

\section{Measurement of corporate social responsibility performance}

Rankins (RKS) database is employed to obtain CSR ratings of our sample firms, which has been widely used in CSR research in the Chinese market (Liao et al., 2018). Corporate social responsibility performance variable is represented by log of CSR ratings released by RKS.

\section{Measurement of independent board}

China Securities Regulatory Commission (CSRC) advocates board independence and clearly states that one-third of the listed companies' board shall comprise independent members. A dummy variable is created on the basis of this one-third criterion, where it is coded as 1 if more than onethird of the directors are independent and 0 otherwise. The CSRC (2001) Guidance Opinion describing an independence test for determining board independence is followed in counting a director as independent or not.

\section{Measurement of family firms}

Majority of the businesses worldwide are run by a dominant shareholder, typically families (Meglio, 2019). Following Biswas, Roberts and Whiting (2019), proportion of family members on board is used as a proxy for family presence (Fam_P), which is calculated as the number of family members on the board divided by board size. Secondly, proxy used for family firms is the family ownership because ownership stake reflects the power an owner holds to influence management decisions. Following Jaggi, Leung and Gul (2009), we classify a firm as family-led at a cut-off of $20 \%$ ownership. A dummy variable (Fam_O) equals 1 if more than $20 \%$ ownership belongs to family members and 0 otherwise.

\section{Measurement of control variables}

Following the literature on CSR, various control variables are included in our regression model to separate the impact of board independence on CSR engagement of a firm. Governance controls include multiple directorships (MD), which is natural $\log$ of the average number of other directorships held by board members. Chief Executive Officer (CEO) duality (CEO_Dual) is measured by a dummy variable that takes the value of 1 if the CEO is also the board's chairman and 0 if a single person does not hold both positions. Presence of CSR committee in a firm is captured by a dummy variable (CSR_Com) having a value of 1 in case of a firm having a separate CSR committee and 0 otherwise. Firm controls include firm size (Size) calculated as log of total sales to standardise absolute values of total sales and to evade the non-normality of the distribution. As a proxy for Slack (SLK), current ratio is used, which is measured as current asset by current liabilities. We control for firm's FP by including Return on Asset as its proxy, which is calculated as a quotient between operating profit and total assets. Firm's indebtedness (INDEBT) is measured as the quotient between total liabilities and total assets. Finally, to control for industry effects (IND), the dummy variables are used because it is possible for CSRP to fluctuate between industries. If the company is active in one of the industries, the dummy variable is assigned a value of 1 and 0 otherwise. Year fixed effect (YEAR) is also controlled for any time trend present in the data. 


\section{Research model}

The following research model examines the effect of board independence on CSRP. To investigate this objective, we regress board independence and other control variables on CSRP of firms:

$$
\begin{aligned}
\operatorname{CSRP}_{i, t}= & \beta_{0}+\beta_{1} \text { Bind }_{i, t}+\text { Governance_controls }_{i, t} \\
& + \text { Firm_controls } \\
i, t & + \text { IND dummies } \\
& + \text { YEAR dummies }+\varepsilon_{i, t}
\end{aligned}
$$

In the family firms' domain, this article investigates the moderating impact of family involvement. In order to study this moderating impact, we regress board independence, family-led firms and the interaction term of board independence and family-led firms on CSRP along with other control variables:

$$
\begin{aligned}
\operatorname{CSRP}_{i, t}= & \beta_{0}+\beta_{1} \text { Bind }_{i . t}+\beta_{2} \text { Fam }_{i, t}+\beta_{3} \operatorname{Bind}_{i . t} * \operatorname{Fam}_{i, t} \\
& + \text { Governance controls }_{i, t}+\text { Firm controls }_{i, t} \\
& + \text { IND dummies }+ \text { YEAR dummies }+\varepsilon_{i, t}
\end{aligned}
$$

where CSRP is the sustainability performance of a firm, Bind is the board independence variable and Fam shows the presence or ownership of the family firms. Governance controls and firm controls are included in the equation. Finally, industry (IND) and time (YEAR) dummy variables are used to control for fixed effects.

\section{Ethical consideration}

This article followed all ethical standards for carrying out a research without direct contact with human or animal subjects.

\section{Empirical findings \\ Descriptive statistics and correlation for regression variables}

Table 1 presents the descriptive statistics and correlations for regression variables. To control for the effect of outliers, all continuous variables are winsorised at $1 \%$ and $99 \%$ of the distribution. The mean score for CSRP is 2.99 , which shows that CSRP for companies averaged about 2.99 over the study period. It is evident from the standard deviation that there exists a high degree of heterogeneity amongst the sample firms with regard to their sustainability performance. Moreover, the fraction of firms having an independent board is very low in our sample; the mean value of Bind is 0.15, which means that $15 \%$ of the firms in the sample have independent boards meeting the one-third criterion of CSRC in its true spirit.

Finally, we note that there is a reasonable degree of family presence in Chinese firms. Thus, we conclude that on average, the non-financial firms in China are headed by family boards. The correlation matrix indicates that Bind positively correlates with CSRP $(0.21, p<0.01)$, whereas Fam_P and Fam_O are negatively correlated with CSRP. All of these findings are aligned with our hypotheses. In addition, MD, CSR_Com, FS, SLK and FP positively correlate with CSRP, whereas CEO_Dual and INDEBT negatively correlate, which is consistent with the results of previous studies (Cruz et al., 2014; Haque, 2017).

\section{Regression analysis}

There is a possibility that CSRP is endogenous, that is, there may be a reverse causality between a firm's sustainability performance and its board independence. To address the concerns over the selection of firms maintaining an independent board, a common approach is to find an instrumental variable (Heckman, 1974). In search of an instrumental variable, we estimated alternative Heckman models but could not find an appropriate one. Thus, to account for the issue of endogeneity, we adopted PSM. Accordingly, a matched sample is selected for firms with

\begin{tabular}{|c|c|c|c|c|c|c|c|c|c|c|c|}
\hline Variable & CSRP & Bind & Fam_P & Fam_O & MD & CEO_D & CSR_Com & Size & SLK & FP & INDEBT \\
\hline Mean & 2.99 & 0.15 & 0.36 & 0.13 & 1.48 & 0.18 & 0.17 & 15.57 & 0.21 & 0.05 & 0.32 \\
\hline Std. dev & 0.81 & 0.35 & 0.29 & 0.33 & 1.23 & 0.39 & 0.39 & 1.49 & 0.42 & 0.10 & 0.10 \\
\hline CSRP & $1^{*}$ & - & - & - & - & - & - & - & - & - & - \\
\hline Bind & $0.23 *$ & $1^{*}$ & - & - & - & - & - & - & - & - & - \\
\hline Fam_P & $-0.51 *$ & $-0.17^{*}$ & $1 *$ & - & - & - & - & - & - & - & - \\
\hline Fam_O & $-0.25 *$ & $-0.07 *$ & $0.27^{*}$ & $1 *$ & - & - & - & - & - & - & - \\
\hline MD & $0.16^{*}$ & -0.01 & -0.03 & $0.03 *$ & $1^{*}$ & - & - & - & - & - & - \\
\hline CEO_D & $-0.16 *$ & $-0.06 *$ & $0.13 *$ & $0.16^{*}$ & -0.01 & $1 *$ & - & - & - & - & - \\
\hline CSR_Com & $0.40 *$ & $0.13 *$ & $-0.22^{*}$ & $-0.06 *$ & $0.08^{*}$ & $-0.03 *$ & $1^{*}$ & - & - & - & - \\
\hline Size & $0.48^{*}$ & $0.13 *$ & $-0.32^{*}$ & $-0.23 *$ & -0.03 & $-0.13 *$ & $0.28 *$ & $1^{*}$ & - & - & - \\
\hline SLK & $0.36^{*}$ & $0.09 *$ & $-0.26 *$ & $-0.08 *$ & $0.07^{*}$ & $-0.07 *$ & $0.31 *$ & $0.15^{*}$ & $1^{*}$ & - & - \\
\hline FP & $0.30 *$ & 0.02 & $-0.15^{*}$ & $-0.16 *$ & $0.23 *$ & $-0.11^{*}$ & $0.15 *$ & $0.16 *$ & $0.22 *$ & $1 *$ & - \\
\hline INDEBT & $-0.25 *$ & $-0.04 *$ & $0.08 *$ & $0.08 *$ & $-0.11 *$ & $0.08 *$ & $-0.12 *$ & 0.01 & $-0.30 *$ & $-0.16 *$ & $1 *$ \\
\hline
\end{tabular}
independent boards (treated group) and for firms without independent boards (control group), which are in other respects sufficiently similar. This control group has firms in which the board is not independent but otherwise matches

TABLE 1: Means, standard deviations and Pearson's correlations for regression variables.

Note: Number of observations $=3960$.

Std. dev, standard deviation; CSRP, corporate social responsibility performance; Fam_P, family presence; Fam_O, Family ownership; CEO_D, CEO duality; CSR_COM, CSR committee; FP, Financial performance of firm; INDEBT, indebtedness.

*, Statistical significance at least at the $5 \%$ level. 
with the attributes of the treated group. In the first step, to create these groups, we follow prior literature (Rosenbaum \& Rubin, 1983) and employ a logit model on the full sample for determining the probability of the firm in having an independent board:

$$
\operatorname{Bind}_{i, t}=\beta_{0}+\beta_{1} \operatorname{Size}_{i . t}+\beta_{2} \text { Growth }_{i . t}+\beta_{3} \operatorname{INDEBT}_{i . t}+\varepsilon_{i t)}
$$

Following Heckman and Navarro-Lozano (2004), we include variables in the logit model presented below to estimate the propensity score that influences both the board independence and the CSRP.

The results reported in Table 2 show that on average firms with independent boards are larger and have more growth opportunities. In addition, the statistically significant likelihood ratio $\left(X^{2}=50.08, p<0.001\right)$ shows the combined significance of the explanatory variables and therefore indicates a good model fit.

In the second step, we used the nearest neighbour method with replacement and the calculated propensity scores to compare firms with independent boards (treatment group) with a sample of control firms without independent boards (control group) matched with the propensity to have an independent board. The propensity-score-matched control sample is generated by matching each firm from the treatment group with up to three firms from the control group having the nearest propensity score. We bound the calliper distance between propensity scores with $5 \%$ so that the absolute difference between the propensity scores for firms with independent boards and its matched peers did not go over 0.05 .

In the third step, the matched and unmatched samples are compared. We expect that firms with independent boards (treated group) and without independent boards (control group) are, on average, different before matching, whereas no significant difference is expected to be present after the procedure of PSM. The matched sample generates 1108 firmyear observations of which 554 observations have independent boards and rest of the observations do not have independent boards. Results of covariate balance analysis are presented in Table 3 to demonstrate the similarity between the treated and control groups, pre- and post-matching. The results indicate that before matching, there was a significant difference between firms in the following characteristics: size and growth. These results point towards the problem of potential self-selection bias in the original sample. Hence, PSM removes the observable difference between each of the characteristics of treatment and control group, whereas the difference between CSRP of these groups remains significant.

Finally, Equations 1 and 2 are estimated using matched samples with weighted standard errors to control for potential endogeneity in data. These weights are calculated
TABLE 2: Estimation of propensity score function and Logit regression.

\begin{tabular}{lcc}
\hline Predictors & Bind & Z-score \\
\hline Size & 0.222 & $5.07 * * *$ \\
Growth & 0.305 & $4.29 * * *$ \\
INDEBT & -0.268 & -0.38 \\
Intercept & -5.762 & $-7.89 * * *$ \\
Obs. & 3960 & - \\
Log likelihood & -774.61 & - \\
Likelihood ratio $X^{2}$ & 50.08 & - \\
Pseudo $R^{2}$ & 0.0313 & - \\
\hline
\end{tabular}

Obs., observations; INDEBT, indebtedness.

$*, * *$ and $* * *$ indicate statistical significance at $10 \%, 5 \%$ and $1 \%$ levels, respectively.

TABLE 3: Pre- and post-matching control variable balance across firms with independent boards and without independent boards.

\begin{tabular}{lcc}
\hline Variables & Pre-PSM sample & Post-PSM sample \\
\hline CSRP & $-0.48^{* * *}$ & $-0.37^{* * *}$ \\
Size & $-0.55^{* * *}$ & -0.05 \\
Growth & $-0.26^{* * *}$ & 0.08 \\
INDEBT & 0.00 & -0.01 \\
Obs. & 3960 & 1108 \\
\hline
\end{tabular}

Note: 'Pre-matching sample' refers to the sample before matching firms having independent boards with non-independent board firms, whereas 'Post-matching sample' refers to the sample after matching.

PSM, propensity score matching; CSRP, corporate social responsibility performance; Obs., observations; INDEBT, indebtedness.

$*, * *$ and $* * *$ indicate statistical significance at $10 \%, 5 \%$ and $1 \%$ levels, respectively

by considering the frequency of firm-year observations in control group used as matches. Table 4 presents the regression results of PSM sample and shows that Bind significantly increases the CSRP of firms (coefficient [coef.] 0.231, $p<0.01$ ). The positive association found between Bind and CSRP allows us to support our first hypothesis, that is, an independent board leads to increased commitment of firms to engage in CSR activities. This result is similar to Haque (2017), who also documented a positive association between the presence of independent boards and CSR engagement of firms. Interaction effects in Table 4 present the result of examining Equation 2, that is, the possible moderating impact of family control on this relationship by introducing Fam_P and Fam_O and their interactions with Bind.

Results show that the interaction term 'BindFam' has a significantly negative impact on CSRP, whilst Bind has still a significantly positive impact, implying that family presence can diminish the positive influence of independent boards on CSRP of firms. This result indicates that independent directors are reluctant about firm's participation in sustainability activities in family firms (coef. Bind + coef. BindFam $=0.290-0.460=-0.170$ ) rather than in non-family firms (coef. 0.290). Results are similar for the additional 'Fam_O' proxy of family-led firms. Overall, the obtained results provide an empirical support to the second hypothesis of this study regarding the moderating effect of family firms on the relationship between the presence of independent boards and sustainability performance. These results imply that the presence of family in business subdues the independence of independent directors. It indicates that independent directors are generally unable to make any significant contribution for CSR promotion, contrary to what is shown in Western literature. Therefore, independent 
TABLE 4: Multiple regression with propensity score matching.

\begin{tabular}{|c|c|c|c|c|c|c|}
\hline \multirow[t]{3}{*}{ Predictors } & \multicolumn{2}{|c|}{ Main effects } & \multicolumn{4}{|c|}{ Interaction effects } \\
\hline & \multirow[t]{2}{*}{ Coefficient } & \multirow[t]{2}{*}{$t$-statistic } & \multicolumn{2}{|c|}{ FAM_P } & \multicolumn{2}{|c|}{ FAM_O } \\
\hline & & & Coefficient & $t$-statistic & Coefficient & $t$-statistic \\
\hline Bind & $0.231 * * *$ & 3.73 & $0.290 * * *$ & 3.4 & $0.260 * * *$ & 4.20 \\
\hline Fam & - & - & $-0.607 * * *$ & -4.14 & -0.089 & 0.55 \\
\hline BindFam & - & - & $-0.460 * *$ & -2.09 & $-0.620 * * *$ & -2.83 \\
\hline MD & $0.077 * * *$ & 2.68 & $0.093 * * *$ & 3.39 & $0.087 * * *$ & 3.09 \\
\hline CEO_Dual & $-0.295 * * *$ & -2.97 & $-0.221^{* *}$ & -2.32 & $-0.283 * * *$ & -2.89 \\
\hline CSR_Com & $0.264 * * *$ & 3.46 & $0.277 * * *$ & 3.82 & $0.376 * * *$ & 4.73 \\
\hline Size & $0.228 * * *$ & 9.20 & $0.191 * * *$ & 7.90 & $0.219 * * *$ & 8.99 \\
\hline SLK & $0.203 * * *$ & 2.95 & $0.186 * * *$ & 2.84 & $0.149 * *$ & 2.18 \\
\hline FP & $1.051 * * *$ & 3.65 & $1.025 * * *$ & 3.73 & $1.019 * * *$ & 3.59 \\
\hline INDEBT & $-0.997 * * *$ & -3.18 & -0.485 & -1.56 & $-0.961 * * *$ & -3.12 \\
\hline Intercept & -0.629 & -1.41 & -0.045 & -0.10 & -0.500 & -1.14 \\
\hline Industry & Included & - & - & - & - & - \\
\hline$N$ & 1108 & - & 1108 & - & 1108 & - \\
\hline Adj. $R^{2}$ & 0.54 & - & 0.58 & - & 0.57 & - \\
\hline
\end{tabular}

Note: The values in parenthesis are $t$-statistic.

Fam, Family involvement through ownership or presence in board; BindFam, interaction term between board independence (Bind) and family involvement (Fam O and Fam P); CEO, Dual is a spelling mistake, its actually; CEO_D, CEO duality; CSR_Com, CSR committee; FP, financial performance; Adj. $R^{2}$, adjusted R squared.

$*, * *$ and $* * *$ indicate statistical significance at $10 \%, 5 \%$ and $1 \%$ levels, respectively.

directors need to be empowered so that they may effectively contribute in corporate decisions. Our results are in accordance with Yusuf, Yousaf and Saeed (2018) that board's independence is generally weakened by the dominant presence of strong social ties and networking within the board. Hence, independent directors also become partners with the management of the firm and thus may not get any forum for exercising their independence.

Regarding control variables, we find them significantly associated with firm's CSRP. Specifically, the regression coefficient for Size is significantly positive, suggesting that larger firms have a positive implication for CSR activities. With the growing size of companies and the consequent increase in their resources, they generally develop CSR plans and aggressively participate in CSR activities in order to satisfy the demands of various stakeholders (McWilliams \& Siegel, 2001). The estimated coefficient for CEO_Dual is negative because $\mathrm{CEO}$ duality results in agency conflicts. It also negatively impacts the effectiveness of the board's monitoring role (Goyal \& Park, 2002), which may reduce the chances of embarking on long-term investment for sustainability projects. Similar to the argument of Peters and Romi (2013), the regression coefficient of CSR_Com is significantly positive. This coefficient shows that the presence of CSR committee symbolises the firm's commitment towards sustainability. The SLK coefficient reported is positively significant, which indicates that the firm's decision to show good citizenship behaviour depends on the resources available. Hence, firms with ample SLK resources devote more funds to sustainability-related activities. According to resource-based view (RBV) and similar to the results of Qiu, Shaukat and Tharyan (2016), the coefficient of FP implies that companies with sufficient financial resources are more likely to be engaged in sustainability-related activities. Significantly, negative coefficient of INDEBT suggests that the payment of interest by highly leveraged firms impedes their spending on social activities because creditors exert pressure on their

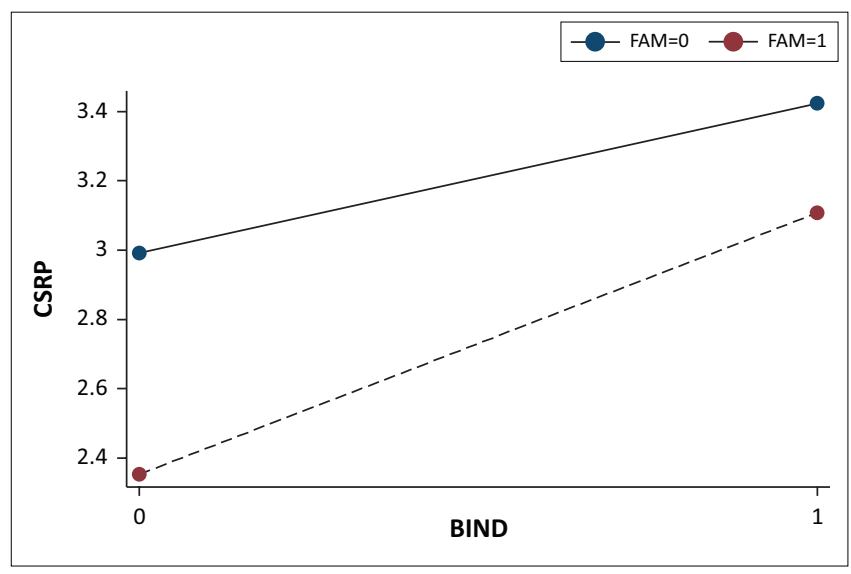

CSRP, corporate social responsibility performance; BIND, board independence.

FIGURE 1: Moderating effect of family on board independence and corporate social responsibility performance relationship. Bind, board independence; CSRP, corporate social responsibility performance.

spending decisions (Brammer \& Pavelin, 2008). Moreover, positive coefficient of MD shows that holding chairs in multiple boards certifies a director's knowledge and diverse experience which help them implement various sustainability practices in their firms.

The graph in Figure 1 shows a buffering interaction effect where family weakens the effect of board independence on CSRP of firms.

\section{Conclusion}

Contemporary literature presents numerous studies, where the relationship between various characteristics of boards and CSR has been explored, with mixed results being obtained. The current study aims to address the issue by establishing an argument that the relationship of board independence and CSRP works differently for family and non-family firms. 
Our results reflect the tendency of independent directors towards an increased involvement in CSR activities, which is in line with the findings of Kao, Yeh, Wang and Fung (2018) reported for Chinese-listed companies. Chinese firms with independent boards exhibit socially responsible behaviour, which is consistent with the premise that independent directors serve in a monitoring capacity over the management on behalf of rest of the stakeholders, and this can affect firms' strategic decisions such as corporate social performance. In addition, our results indicate that independent directors are influenced in their decision-making as per the conduct of family members on the board.

Cumulatively, the results reveal that independent directors are primarily more inclined towards the concerns of family members, as their appointments are generally made based on family links or friendships. Therefore, it appears that independent directors usually work in line with the interests of the controlling families who are largely concerned about financial issues in comparison to CSR practices. Explicitly, we indicate that family members preserve their influence in firms, regardless of the governance system in place. Our findings support the recently evolved argument, which highlights the ineffectiveness of board independence in the firms of developing countries, where concentrated ownership or family control is common.

The findings of our current work have practical implications. The environmental threats are evident and social performance of firms is under observation. Moreover, CG failures are partly considered responsible for the continuing weak financial conditions of firms. Such circumstances encourage all relevant stakeholders, including regulating bodies, government agencies, etc., to pressurise firms for improving their sustainability performance. Our results would help these authorities in designing regulatory programmes by guiding them in developing customised policies for different governnance and ownership systems in place. Our findings recommend that firms based on closely held ownership need to be given serious attention. In addition, in a bid to attain improved sustainability performance, diversified shareholding may be favoured or requisite codes may be framed to enhance the social performance of firms having concentrated ownership.

This work essentially clears the varying results in literature with regard to the relationship between board characteristics and firms' CSRP. Moreover, our work is an important advancement in the literature in terms of presenting the family firm as a variable that directs the choice of independent directors to carry out CSR activities.

Finally, the results also hint at exploring further moderating and mediating variables for extracting more meaningful insights into this relationship. There appears an interesting research direction, where the positive and negative effects of CSRP of a firm can be evaluated with the presence of independent members on the board, considering the conditions and context, where independent directors are able to perform well. Government, institutional investors and foreign investors can be considered as relevant shareholders for future research to obtain more comprehensive results. The influence of such shareholders could be beneficial in terms of not supporting the decisions of family members. Furthermore, in this way, the focussed interest on FP of family members could also be well mitigated by other owners, by considering the demands of various stakeholders.

This study has few limitations that could be addressed in future researches. Our article has treated family firms as homogeneous entities. This practice over-generalises the results and limits the explanatory power. Hence, we recommend future researchers to incorporate family heterogeneity, for example, single versus multi-generation, etc., in extending this research model. Moreover, our analysis is based on data from a single country, that is, China, which confines the generalisability of results. Cross-country comparisons could be performed in future studies to establish whether our results hold.

\section{Acknowledgements}

The authors thank the Higher Education Commission of Pakistan for funding this research.

\section{Competing interests}

The authors have declared that no competing interest exists.

\section{Authors' contributions}

R.A. conceptualised the research idea and wrote the article, and J.A. supervised the study.

\section{Funding information}

This research is funded by the Higher Education Commission of Pakistan.

\section{Data availability statement}

Data can be made available on request.

\section{Disclaimer}

The views and opinions expressed in this article are those of the authors and do not necessarily reflect the official policy or position of any affiliated agency of the authors.

\section{References}

Al-Dah, B. (2019). Director interlocks and the strategic pacing of CSR activities. Management Decision, 57(10), 2782-2798. https://doi.org/10.1108/MD-112017-1103

Albuquerque, R., Koskinen, Y., \& Zhang, C. (2018). Corporate social responsibility and firm risk: Theory and empirical evidence. Management Science, 65(10), 44514469. https://doi.org/10.1287/mnsc.2018.3043

Bansal, S., Lopez-Perez, V.M., \& Rodriguez-Ariza, L. (2018). Board independence and corporate social responsibility disclosure: The mediating role of the presence of family ownership. Administrative Sciences, 8(3), 1-21. https://doi.org/10.3390/ admsci8030033 
Bardhan, I., Lin, S., \& Wu, S.-L. (2014). The quality of internal control over financial reporting in family firms. Accounting Horizons, 29(1), 41-60. https://doi. org/10.2308/acch-50935

Bing, T., \& Li, M. (2019). Does CSR signal the firm value? Evidence from China. Sustainability, 11(15), 4255. https://doi.org/10.3390/su11154255

Biswas, P.K., Roberts, H., \& Whiting, R.H. (2019). The impact of family vs non-family governance contingencies on CSR reporting in Bangladesh. Management Decision 57(10), 2758-2781. https://doi.org/10.1108/MD-11-2017-1072

Blodgett, M.S., Dumas, C., \& Zanzi, A. (2011). Emerging trends in global ethics: A comparative study of U.S. and international family business values. Journal of Business Ethics, 99(1), 29-38. https://doi.org/10.1007/s10551-011-1164-7

Brammer, S., \& Pavelin, S. (2008). Factors influencing the quality of corporate environmental disclosure. Business Strategy and the Environment, 17(2), 120-136. https://doi.org/10.1002/bse.506

Chang, Y., Oh, W.-Y., Park, J., \& Jang, M. (2017). Exploring the relationship between board characteristics and CSR: Empirical evidence from Korea. Journal of Business Ethics, 140(2), 225-242. https://doi.org/10.1007/s10551-015-2651-z

Chen, H.-L., Hsu, W.-T., \& Chang, C.-Y. (2016). Independent directors' human and social capital, firm internationalization and performance implications: An integrated agency-resource dependence view. International Business Review, 25(4) 859-871. https://doi.org/10.1016/j.ibusrev.2015.10.010

Cho, D.-S., \& Kim, J. (2007). Outside directors, ownership structure and firm profitability in Korea. Corporate Governance: An International Review, 15(2), profitability in Korea. Corporate Governance: An Internationa
239-250. https://doi.org/10.1111/j.1467-8683.2007.00557.x

Chrisman, J.J., Memili, E., \& Misra, K. (2014). Nonfamily managers, family firms, and the winner's curse: The influence of noneconomic goals and bounded rationality. Entrepreneurship Theory and Practice, 38(5), 1-25. https://doi.org/10.1111/ etap.12014

Chrisman, J.J., \& Patel, P.C. (2012). Variations in R\&D investments of family and nonfamily firms: Behavioral agency and myopic loss aversion perspectives. Academy of Management Journal, 55(4), 976-997. https://doi.org/10.5465/ amj.2011.0211

Chu, W. (2011). Family ownership and firm performance: Influence of family management, family control, and firm size. Asia Pacific Journal of Management, 28(4), 833-851. https://doi.org/10.1007/s10490-009-9180-1

Collin, S.-O.Y., \& Ahlberg, J. (2012). Blood in the boardroom: Family relationships influencing the functions of the board. Journal of Family Business Strategy, 3(4) 207-219. https://doi.org/10.1016/j.jfbs.2012.11.001

Corbetta, G., \& Salvato, C.A. (2004). The board of directors in family firms: One size fits all? Family Business Review, 17(2), 119-134. https://doi.org/10.1111/j.1741 6248.2004.00008.x

Cruz, C., Larraza-Kintana, M., Garcés-Galdeano, L., \& Berrone, P. (2014). Are family firms really more socially responsible? Entrepreneurship Theory and Practice, 38(6), 1295-1316. https://doi.org/10.1111/etap.12125

China Securities Regulatory Commission (CSRC). (2001). Guidelines for introducing independent directors to the board of directors of listed companies. People's Republic of China: China Securities Regulatory Commission.

Cuadrado-Ballesteros, B., Rodríguez-Ariza, L., \& García-Sánchez, I.-M. (2015). The role of independent directors at family firms in relation to corporate social responsibility disclosures. International Business Review, 24(5), 890-901. https:// responsibility disclosures. International
doi.org/10.1016/j.ibusrev.2015.04.002

Darmadi, S. (2013). Information disclosure by family-controlled firms: The role of board independence and institutional ownership. Asian Review of Accounting, 21(3), 223-240. https://doi.org/10.1108/ARA-01-2013-0009

De Massis, A., Chirico, F., Kotlar, J., \& Naldi, L. (2013). The temporal evolution of proactiveness in family firms: The horizontal S-Curve hypothesis. Family Business Review, 27(1), 35-50. https://doi.org/10.1177/0894486513506114

De Villiers, C., Naiker, V., \& Van Staden, C.J. (2011). The effect of board characteristics on firm environmental performance. Journal of Management, 37(6), 1636-1663. https://doi.org/10.1177/0149206311411506

Du, X., Weng, J., Zeng, Q., Chang, Y., \& Pei, H. (2017). Do lenders applaud corporate environmental performance? Evidence from Chinese private-owned firms. Journal of Business Ethics, 143(1), 179-207. https://doi.org/10.1007/s10551-0152758-2

Frias-Aceituno, J.V., Rodriguez-Ariza, L., \& Garcia-Sanchez, I.M. (2013). The role of the board in the dissemination of integrated corporate social reporting. Corporate Social Responsibility and Environmental Management, 20(4), 219-233. https:// doi.org/10.1002/csr.1294

Gabrielsson, J., \& Huse, M. (2005). Outside directors in SME boards: A call for theoretical reflections. Corporate Board: Role, Duties and Composition, 1, 28-37. https://doi.org/10.22495/cbv1i1art3

García-Ramos, R., \& García-Olalla, M. (2011). Board characteristics and firm performance in public founder- and nonfounder-led family businesses. Journal of Family Business Strategy, 2(4), 220-231. https://doi.org/10.1016/j.jfbs.2011.09.001

Garcia-Sanchez, I.-M. (2014). Does media pressure moderate CSR disclosures by external directors? Management Decision, 52(6), 1014-1045. https://doi. org/10.1108/MD-09-2013-0446

García-Sánchez, I.M., Gómez-Miranda, M.E., David, F., \& Rodríguez-Ariza, L. (2019). Board independence and GRI-IFC performance standards: The mediating effect of the CSR committee. Journal of Cleaner Production, 225(29), 554-562. https://doi. org/10.1016/j.jclepro.2019.03.337

Goh, B.W., Lee, J., Ng, J., \& Ow Yong, K. (2016). The effect of board independence on information asymmetry. European Accounting Review, 25(1), 155-182. https:// doi.org/10.1080/09638180.2014.990477
Gomez-Mejia, L., Cruz, C., \& Imperatore, C. (2014). Financial reporting and the protection of socioemotional wealth in family-controlled firms. European Accounting Review, 23(3), 387-402. https://doi.org/10.1080/09638180.2014.944420

Goyal, V.K., \& Park, C.W. (2002). Board leadership structure and CEO turnover. Journal of Corporate Finance, 8(1), 49-66. https://doi.org/10.1016/S0929-1199(01)00028-1

Guerrero-Villegas, J., Pérez-Calero, L., Hurtado-González, M.J., \& Giráldez-Puig, P. (2018). Board attributes and corporate social responsibility disclosure: A metaanalysis. Sustainability, 10(12), 4808. https://doi.org/10.3390/su10124808

Haque, F. (2017). The effects of board characteristics and sustainable compensation policy on carbon performance of UK firms. The British Accounting Review, 49(3), 347-364. https://doi.org/10.1016/j.bar.2017.01.001

Heckman, J. (1974). Shadow prices, market wages, and labor supply. Econometrica, 42(4), 679-694. https://doi.org/10.2307/1913937

Heckman, J., \& Navarro-Lozano, S. (2004). Using matching, instrumental variables, and control functions to estimate economic choice models. Review of Economics and Statistics, 86(1), 30-57. https://doi.org/10.1162/003465304323023660

Hooy, G.-K., Hooy, C.-W., \& Chee, H.-K. (2019). Ultimate ownership, control mechanism, and firm performance: Evidence from Malaysian firms. Emerging Markets Finance and Trade, 1-24. https://doi.org/10.1080/1540496X.2019.1584101

Hu, Y.Y., Zhu, Y., Tucker, J., \& Hu, Y. (2018). Ownership influence and CSR disclosure in China. Accounting Research Journal, 31(1), 8-21. https://doi.org/10.1108/ARJ-012017-0011

Jaggi, B., Leung, S., \& Gul, F. (2009). Family control, board independence and earnings management: Evidence based on Hong Kong firms. Journal of Accounting and Public Policy, 28(4), 281-300. https://doi.org/10.1016/j.jaccpubpol.2009.06.002

Jizi, M. (2017). The influence of board composition on sustainable development disclosure: Board composition and sustainable development disclosure. Business Strategy and the Environment, 26(5), 640-655. https://doi.org/10.1002/bse.1943

Kao, E.H., Yeh, C.-C., Wang, L.-H., \& Fung, H.-G. (2018). The relationship between CSR and performance: Evidence in China. Pacific-Basin Finance Journal, 51, 155-170. https://doi.org/10.1016/j.pacfin.2018.04.006

Kellermanns, F.W., Eddleston, K.A., \& Zellweger, T.M. (2012). Article commentary: Extending the socioemotional wealth perspective: A look at the dark side. Entrepreneurship Theory and Practice, 36(6), 1175-1182. https://doi. Entrepreneurship Theory and Practic
$\mathrm{org} / 10.1111 / \mathrm{j} .1540-6520.2012 .00544 . x$

Labelle, R., Hafsi, T., Francoeur, C., \& Ben Amar, W. (2018). Family firms' corporate social performance: A calculated quest for socioemotional wealth. Journal of Business Ethics, 148(3), 511-525. https://doi.org/10.1007/s10551-015-2982-9

Leung, S., Richardson, G., \& Jaggi, B. (2014). Corporate board and board committee independence, firm performance, and family ownership concentration: An analysis based on Hong Kong firms. Journal of Contemporary Accounting \& Economics, 10(1), 16-31. https://doi.org/10.1016/j.jcae.2013.11.002

Liao, L., Lin, T., \& Zhang, Y. (2018). Corporate board and corporate social responsibility assurance: Evidence from China. Journal of Business Ethics, 150(1), 211-225. https://doi.org/10.1007/s10551-016-3176-9

Liao, L., Luo, L., \& Tang, Q. (2015). Gender diversity, board independence, environmental committee and greenhouse gas disclosure. The British Accounting Review, 47(4), 409-424. https://doi.org/10.1016/j.bar.2014.01.002

McWilliams, A., \& Siegel, D. (2001). Profit maximizing corporate social responsibility. Academy of Management Review, 26(4), 504-505. https://doi.org/10.2307/ 259398

Meglio, O. (2019). Family businesses: Building a merger and acquisition research agenda. In R. King David, L.C. Cary \& F. Sydney (Eds.), Advances in mergers and acquisitions (vol. 18, pp. 83-98). Bingley: Emerald Publishing Limited.

Miller, D., \& Le Breton-Miller, I. (2006). Family governance and firm performance: Agency, stewardship, and capabilities. Family Business Review, 19(1), 73-87. https://doi.org/10.1111/j.1741-6248.2006.00063.x

Mokhtar, N., Jusoh, R., \& Zulkifli, N. (2016). Corporate characteristics and environmental management accounting (EMA) implementation: Evidence from Malaysian public listed companies (PLCS). Journal of Cleaner Production, 136, 111-122. https://doi.org/10.1016/j.jclepro.2016.01.085

Morck, R., \& Yeung, B. (2003). Agency problems in large family business groups. Entrepreneurship Theory and Practice, 27(4), 367-382. https://doi.org/10.1111/ 1540-8520.t01-1-00015

Muttakin, M.B., Khan, A., \& Mihret, D.G. (2018). The effect of board capital and CEO power on corporate social responsibility disclosures. Journal of Business Ethics, 150(1), 41-56. https://doi.org/10.1007/s10551-016-3105-y

Nekhili, M., Nagati, H., Chtioui, T., \& Rebolledo, C. (2017). Corporate social responsibility disclosure and market value: Family versus nonfamily firms. Journal of Business Research, 77(C), 41-52. https://doi.org/10.1016/j.jbusres. Journal of Busin

Peters, G., \& Romi, A. (2013). The association between sustainability governance characteristics and the assurance of corporate sustainability reports. AUDITING: $A$ Journal of Practice \& Theory, 34(1), 163-198. https://doi.org/10.2139/ssrn.2198068

Pohl, M., \& Tolhurst, N. (2010). Responsible business: How to manage a CSR strategy successfully. Chichester, West Sussex: John Wiley \& Sons.

Qiu, Y., Shaukat, A., \& Tharyan, R. (2016). Environmental and social disclosures: Link with corporate financial performance. The British Accounting Review, 48(1) 102-116. https://doi.org/10.1016/j.bar.2014.10.007

Ramón-Llorens, M.C., García-Meca, E., \& Pucheta-Martínez, M.C. (2018). The role of human and social board capital in driving CSR reporting. Long Range Planning, 52(6), 101846. https://doi.org/10.1016/j.Irp.2018.08.001

Roe, M.J. (1991). A political theory of American corporate finance. Columbia Law Review, 91(1), 10-67. https://doi.org/10.2307/1122856 
Rosenbaum, P.R., \& Rubin, D.B. (1983). The central role of the propensity score in observational studies for causal effects. Biometrika, 70(1), 41-55. https://doi. org/10.1093/biomet/70.1.41

Saeidi, S.P., Sofian, S., Saeidi, P., Saeidi, S.P., \& Saaeidi, S.A. (2015). How does corporate social responsibility contribute to firm financial performance? The mediating role of competitive advantage, reputation, and customer satisfaction. Journal of Business Research, 68(2), 341-350. https://doi.org/10.1016/j.jbusres.2014.06.024

Singal, M. (2014). Corporate social responsibility in the hospitality and tourism industry: Do family control and financial condition matter? International Journal of Hospitality Management, 36, 81-89. https://doi.org/10.1016/j.ijhm.2013.08.002

Tate, W., \& Bals, L. (2018). Achieving shared triple bottom line (TBL) value creation: Toward a social resource-based view (SRBV) of the firm. Journal of Business Ethics, 152(3), 803-826. https://doi.org/10.1007/s10551-016-3344-y

Tauringana, V. \& Chithambo, L. (2015). The effect of DEFRA guidance on greenhouse gas disclosure. The British Accounting Review, 47(4), 425-444. https://doi. org/10.1016/j.bar.2014.07.002
Wang, J., \& Dewhirst, H.D. (1992). Boards of directors and stakeholder orientation Journal of Business Ethics, 11(2), 115-123. https://doi.org/10.1007/BF00872318

Yu, A., Lumpkin, G.T., Sorenson, R.L., \& Brigham, K.H. (2011). The landscape of family business outcomes: A summary and numerical taxonomy of dependent variables. Family Business Review, 25(1), 33-57. https://doi.org/10.1177/0894486511430329

Yuan, D., Hua, Z., \& Junxi, Z. (2008). The financial and operating performance of Chinese family-owned listed firms. Management International Review, 48(3), 297-318. https://doi.org/10.1007/s11575-008-0017-9

Yusuf, F., Yousaf, A., \& Saeed, A. (2018). Rethinking agency theory in developing countries: A case study of Pakistan. Accounting Forum, 42(4), 281-292. https:// doi.org/10.1016/j.accfor.2018.10.002

Zellweger, T.M., Nason, R.S., Nordqvist, M., \& Brush, C.G. (2013). Why do family firms strive for nonfinancial goals? An organizational identity perspective Entrepreneurship Theory and Practice, 37(2), 229-248. https://doi.org/10.1111/j.1540-6520.2011. 00466.x 